\title{
Apoptosis in the course of granulomatous inflammation in pulmonary sarcoidosis
}

\author{
R. Kunitake, K. Kuwano, H. Miyazaki, N. Hagimoto, Y. Nomoto, N. Hara
}

\begin{abstract}
Apoptosis in the course of granulomatous inflammation in pulmonary sarcoidosis. $R$. Kunitake, K. Kuwano, H. Miyazaki, N. Hagimoto, Y. Nomoto, N. Hara. (C) ERS Journals Ltd 1999.

ABSTRACT: Sarcoidosis is a chronic inflammatory disease of unknown aetiology characterized by the formation of non-necrotizing granulomas. The course of disease is usually self-limiting with the spontaneous resolution of granuloma. In the immune system, Fas antigen (Fas) and Fas ligand (FasL) are involved in the down regulation of immune reactions by inducing apoptosis. Therefore, it was hypothesized that the Fas/ FasL pathway and apoptosis may be associated with the course of granulomatous inflammation in sarcoidosis.

Terminal deoxynucleotidyl transferase-mediated biotin nick end-labelling (TUNEL) was performed to assess deoxyribonucleic acid strand breakages as a characteristic of apoptosis. Immunohistochemistry was also performed to detect Fas and FasL protein, and reverse transcriptase polymerase chain reaction (RT-PCR) and RT in situ PCR to detect FasL messenger ribonucleic acid (mRNA).

Positive signals for TUNEL were detected in epithelioid histiocytes and lymphocytes within granulomas and in bronchoalveolar lavage (BAL) lymphocytes from patients with sarcoidosis. Positive signals for Fas were also detected in these cells. FasL mRNA was expressed in BAL lymphocytes from 15 of 20 patients with sarcoidosis, but from only one of 10 patients with normal lung parenchyma. FasL protein was expressed in lymphocytes surrounding and within the granuloma. There was a significant correlation between the result of TUNEL and clinical course in patients with sarcoidosis.

Apoptosis in epithelioid histiocytes and inflammatory cells seems to participate in the course of granulomatous inflammation. Further studies are needed to determine the role of Fas, FasL and other regulatory factors in apoptosis in the granulomatous inflammation in pulmonary sarcoidosis.
\end{abstract}

Eur Respir J 1999; 13: 1329-1337.

Research Institute for Diseases of the Chest, Faculty of Medicine, Kyushu University, Higashiku, Fukuoka, Japan.

\section{Correspondence: K. Kuwano}

Research Institute for Diseases of the Chest Faculty of Medicine

Kyushu University

3-1-1 Maidashi

Higashiku

Fukuoka 812-8582

Japan.

Fax: 81926425389

Keywords: Apoptosis
Fas
Fas ligand
granuloma
sarcoidosis

Received: July 81998

Accepted after revision March 111999

This work was supported by a Grant-inAid for Scientific Research (09670620) from the Ministry of Education, Science and Culture of Japan.
Fas antigen (Fas) is a cell surface protein that mediates apoptosis. It is a member of the nerve growth factor/tumour necrosis factor (TNF) receptor family. It is expressed in various cells and tissues including the thymus, liver, ovary, heart and lung [1]. Fas ligand (FasL) is a type II membrane protein that is a member of the TNF family. FasL is expressed predominantly in activated T-lymphocytes and in several tissues including small intestine, kidney, testis and lung [2]. When cross-linked with FasL, Fas mediates apoptosis of Fas-bearing cells. In the immune system, Fas and FasL are involved in the downregulation of immune reactions [3-5].

It is now increasingly recognized that unwanted cells may be cleared by apoptosis, which eliminates cells without inciting an inflammatory response. Polunovsky et al. [6] have demonstrated the presence of signals capable of inducing the death of the cellular elements of granulation tissues during the repair after acute lung injury. Apoptosis of unwanted cells in the remodelling process is an important mechanism for the resolution of inflammation and for the repair of injured lung tissue.

Sarcoidosis is a multisystem granulomatous disorder of unknown aetiology most commonly affecting young adults and frequently presenting with bilateral lymphadenopathy, pulmonary infiltration, and skin or eye lesions. In sarcoidosis the disease activity can frequently resolve spontaneously or as a result of corticosteroid therapy. Granulomas often resolve spontaneously, without the prolongation of inflammation or remaining fibrosis.

The mechanisms by which granulomas of sarcoidosis resolve have not been well established. It is thought that the resolution of granulomatous inflammation may be induced by withdrawal of inflammatory cytokines and/or by induction of suppressive signals for those cytokines. To resolve without prolongation of inflammation or fibrosis, epithelioid histiocytes, fibroblasts, and inflammatory cells, should be eliminated without undesirable side-effects. Therefore, it was hypothesized that apoptosis and the Fas/FasL system may associate with the course of granulomatous inflammation in pulmonary sarcoidosis. The presence and distribution of deoxyribonucleic acid (DNA) strand breakages was investigated as a characteristic of apoptosis by the method of terminal deoxynucleotidyl transferase (TdT)mediated deoxyuridine triphosphate (dUTP)-biotin nick end-labelling (TUNEL) in lung tissues and bronchoalveolar lavage (BAL) cells from patients with pulmonary sarcoidosis. The expression of Fas protein in lung tissues and BAL cells, and FasL in lung tissues were investigated 
using immunohistochemistry (IHC), and the expression of FasL messenger ribonucleic acid (mRNA) in BAL cells was examined using RT-PCR and RT in situ PCR.

\section{Materials and methods}

\section{Case material}

Twenty patients with histologically proven pulmonary sarcoidosis were investigated. All cases studied had clinical characteristics of sarcoidosis. Lung samples were obtained by transbronchial lung biopsy (TBLB) and by BAL. In all cases, examinations were performed before corticosteroid administration. There were 10 males and 10 females, age range 24-68 yrs (mean 42 yr), 10 were smokers and 10 were nonsmokers. The results in these patients were compared with those in 10 normal lung parenchyma specimens obtained by lobectomy for solitary pulmonary nodule. The control subjects were six males and four females, age range 56-78 yrs (mean $67 \mathrm{yr}$ ), eight were smokers and two were nonsmokers.

\section{Tissue preparation}

Tissue samples were fixed in $10 \%$ formalin overnight, and embedded in paraffin. Two $5 \mu \mathrm{m}$ paraffin sections were adhered to slides pretreated with poly-L-lysine. Paraffin was removed by heating the sections for $1 \mathrm{~h}$ at $70^{\circ} \mathrm{C}$. These sections were dewaxed by washing three times for 5 min each in xylene, then rehydrated in $100 \%$, $95 \%$, and $80 \%$ ethanol, for $5 \mathrm{~min}$ each, and finally rinsed with distilled water.

\section{Analysis of BAL cells}

BAL cells were obtained from 20 patients with sarcoidosis and from 10 patients with normal lung parenchyma. BAL was performed using a total of $150 \mathrm{~mL}$ of sterile physiological saline solution. The recovered fluid was filtered through a single layer of gauze to remove mucus. Cells used for immunohistochemistry and reverse transcriptase (RT) in situ polymerase chain reaction (PCR) were placed on poly-L-lysin coated slides using cytospin, fixed with 4\% paraformaldehyde for $15 \mathrm{~min}$, and frozen for storage. Cells in the lavage fluid were counted using a haemocytometer. Differential counts were performed on a total of 100 cells stained with Wright and Giemsa stain.

\section{Immunohistochemistry for Fas and FasL protein}

Following removal of paraffin in xylene and rehydration in ethanol, the tissue sections were autoclaved at $120^{\circ} \mathrm{C}$ for $20 \mathrm{~min}$ in a stainless steel pot, filled with distilled water to completely immerse the sections (hydrated autoclaving) [7], washed three times in $0.1 \mathrm{M}$ phosphate-buffered saline (PBS). Removal of paraffin was not applied to immunohistochemistry in BAL cells. Immunohistochemistry was performed using a modified streptavidin-biotinylated peroxidase technique using a Histofine SAB-PO kit from Nichirei Corporation (Tokyo, Japan). Nonspecific protein staining was blocked by rabbit serum for $15 \mathrm{~min}$ at room temperature. The sections were incubated with mouse anti-human Fas antibody (UB2) (MBL; Nagoya, Japan) or mouse anti-human FasL antibody (NOK1) (Pharmingen, San Diego, CA, USA) overnight at $4{ }^{\circ} \mathrm{C}$. The sections were rinsed with PBS and incubated with biotinylated rabbit anti-mouse immunoglobulin for 15 min, washed and treated with $0.3 \%$ hydrogen peroxide to inhibit the activity of any endogenous peroxidase in methanol for $30 \mathrm{~min}$. The slides were washed, incubated with streptavidin-biotin peroxidase complex for $30 \mathrm{~min}$, and developed according to the manufacturer's directions. For control incubations, mouse anti-human Fas antibody and mouse anti-human FasL antibody were replaced by nonimmune mouse immunoglobulin (Ig)G.

\section{In Situ DNA nick end-labelling (TUNEL)}

TUNEL was performed in lung tissues and in BAL cells according to the protocols described by GAVRIELI et al. [8] with slight modifications as previously described [9].

\section{RT-PCR for FasL mRNA in BAL cells}

RNA from BAL cells was prepared by the method of WILKINSON [10]. Briefly, the cytoplasmic membrane of BAL cells was treated with the lysis buffer $(22.5 \mathrm{mM}$ Tris- $\mathrm{HCl}, 0.12 \mathrm{M} \mathrm{NaCl}, 4.5 \mathrm{mM} \mathrm{KCl}, 1 \%$ Triton X-100, $0.5 \%$ sodium deoxycholate, and $0.01 \%$ dextran sulphate), centrifuged, and the supernatant was subjected to phenol: chloroform extraction. For the PCR analysis of RNA, complementary DNA (cDNA) was prepared by reverse transcription of $1 \mu \mathrm{g}$ of each RNA sample in a $20-\mu \mathrm{L}$ reaction volume containing $10 \mathrm{mM}$ Tris $\mathrm{HCl}(\mathrm{pH} 8.8), 50$ $\mathrm{mM} \mathrm{KCl}, 4 \mathrm{mM} \mathrm{MgCl} 2,0.1 \%$ Triton X-100, $1 \mathrm{mM}$ dithiothreitol (DTT), $0.25 \mathrm{mM}$ deoxyribonucleoside triphosphate (dNTPs), $5 \mu \mathrm{M}$ random hexamer primers, 0.1 $\mathrm{U} \cdot \mu \mathrm{L}^{-1}$ of ribonuclease inhibitor (Promega Corp., Madison, WI, USA) and $10 \mathrm{U} \cdot \mu \mathrm{L}^{-1}$ of Molony-murine leukaemia virus reverse transcriptase (MMLV-RT) (GIBCO BRL, Gaithersburg, MD, USA). The reaction mixture was incubated at $42^{\circ} \mathrm{C}$ for $1 \mathrm{~h}$, and at $95^{\circ} \mathrm{C}$ for $5 \mathrm{~min}$. The cDNAs were then diluted to $50 \mu \mathrm{L}$, and the same DNA mixtures were used in all PCRs. PCRs were performed in a $50-\mu \mathrm{L}$ reaction volume containing $5 \mu \mathrm{L}$ of each cDNA, $10 \mathrm{mM}$ Tris $\mathrm{HCl}(\mathrm{pH} 8.8), 50 \mathrm{mM} \mathrm{KCl}, 1.5 \mathrm{mM} \mathrm{MgCl}_{2}$ for FasL PCR or $2.5 \mathrm{mM} \mathrm{MgCl}_{2}$ for $\beta$-actin PCR, $0.1 \%$ Triton X100, $0.2 \mathrm{mM}$ dNTPs, and $1.25 \mathrm{U}$ of Taq polymerase (Takara, Otsu, Japan). The primers and probes used are as follows. For $\beta$-actin: sense 5 '-TCCTGTGGCATCCATGAAACT-3', antisense 5'-CTTCGTGAACGCCACGTGCTA-3'; probe 5'- GGAGATTACTGCTCTGGCTC-3'. For FasL: sense 5'-ATCCCTCTGGAATGGGAAGA-3'; antisense 5'-CCATATCTGTCCAGTAGTGC-3'; probe 5'-GAGGATCTGGTGCTAATGGA-3'.

The conditions for amplification were as follows: $93^{\circ} \mathrm{C}$ for $3 \mathrm{~min}$ for $1 \mathrm{cycle}, 93^{\circ} \mathrm{C}$ for $1 \mathrm{~min}, 55^{\circ} \mathrm{C}$ for $1 \mathrm{~min}, 72^{\circ} \mathrm{C}$ for $2 \mathrm{~min}$ for 35 cycles, and $72^{\circ} \mathrm{C}$ for $7 \mathrm{~min}$ for 1 cycle. Cycle curve studies confirmed that, for the amounts of cDNA being amplified, the reactions had not reached the plateau of the amplification curve for any primer pair. Negative controls performed with no RT yielded no 
detectable fragments with either primer pair. PCR products were transferred to filters, and hybridized with an oligonucleotide probe labelled with digoxigenin-dUTP by using the DIG Oligonucleotide 3'-End Labelling Kit (Boehringer Mannheim, Mannheim, Germany). Hybridizations were performed according to the manufacturer's recommendation, and digoxigenin-labelled probe which hybridized with PCR products was detected with the DIG Nucleic Acid Detection Kit (Boehringer Mannheim).

\section{$R T$ in situ PCR analysis for FasL $m R N A$ in BAL cells}

BAL cells were analysed by the RT in situ PCR for FasL mRNA. RT in situ PCR was performed as previously described [11] according to the protocols of NuOvo [12]. Briefly, poly-L-lysin coated slides containing BAL cells were fixed in $10 \%$ buffered formalin for $8 \mathrm{~h}$. The specimen was immersed in $20 \mu \mathrm{g} \cdot \mathrm{mL}^{-1}$ proteinase $\mathrm{K}$, then treated overnight with a ribonuclease (RNase)-free deoxyribonuclease (DNase) I (GIBCO BRL) at $37^{\circ} \mathrm{C}$. The specimens were incubated on the glass slide at $42^{\circ} \mathrm{C}$ for $30 \mathrm{~min}$ with $10 \mu \mathrm{L}$ of a solution which contained the downstream primer $(1 \mu \mathrm{M})$ and MMLV-RT (GIBCO BRL). The solution for the amplification of the FasL cDNA contained $4.5 \mathrm{mM} \mathrm{MgCl} 2,200 \mu \mathrm{M}$ each of dNTPs, $10 \mu \mathrm{M}$ digoxigenin-11-dUTP, $1 \mu \mathrm{M}$ of each primer, $100 \mu \mathrm{g} \cdot \mathrm{mL}^{-1}$ of bovine serum albumin (BSA), and 5 $\mathrm{U}$ of Taq polymerase (Takara) $/ 25 \mu \mathrm{L}$ amplifying solution. The conditions for amplification were $93^{\circ} \mathrm{C}$ for $1 \mathrm{~min}$, $55^{\circ} \mathrm{C}$ for $2 \mathrm{~min}$ for 20 cycles. The digoxigenin-11-dUTP labelled PCR product was detected after incubation with an anti-digoxigenin alkaline phosphatase conjugate for 30 min and developed in the nitroblue tetrazolium (NBT)/5Bromo-4 chloro-3-indolyl Phosphate (BCIP) colour re- action solution for $30 \mathrm{~min}$ in a dark room. The positive control for RT in situ PCR was to eliminate the DNase digestion. An intense nuclear signal was generated from the target-specific amplification, DNA repair, and mispriming. The negative control was RT in situ PCR in which the tissue was treated with DNase I and the RT step was eliminated. The absence of a signal demonstrated that the amplification of genomic DNA was not occurring.

\section{Statistical analysis}

Statistical analyses were performed using Fisher's exact probability test and Student's t-test. A p-value of $<0.05$ was considered statistically significant.

\section{Results}

\section{Clinical features of patients studied}

The patient characteristics are summarized in table 1. BAL data are shown in table 2. The disease course was estimated by radiographic and clinical findings. Eighteen of 20 patients have been followed for 2-6 yrs. Of these, 10 have improved, while eight still have active diseases. The course of two patients (numbers 2 and 8 ) is unknown.

\section{TUNEL positive cells}

The frequency of TUNEL positive cells in the granulomatous lung tissue was graded from 0 to 3 according to the percentage of nuclei stained: graded as $0,<10 \% ; 1,10$ $20 \% ; 2,20-50 \% ; 3,>50 \%$. TUNEL positive cells were also quantified more precisely in epithelioid granuloma

Table 1. - Clinical features of sarcoidosis patients

\begin{tabular}{|c|c|c|c|c|c|c|c|c|c|}
\hline $\begin{array}{l}\text { Patient } \\
\text { No. }\end{array}$ & $\begin{array}{l}\text { Age } \\
\text { yrs }\end{array}$ & Sex & $\begin{array}{c}\text { Radiographic } \\
\text { stage }\end{array}$ & $\begin{array}{l}\text { Smoking } \\
\text { (BI) }\end{array}$ & $\mathrm{ACE}$ & $\begin{array}{l}\text { Extra- } \\
\text { thoracic }\end{array}$ & $\begin{array}{l}\mathrm{VC} \\
\%\end{array}$ & $\begin{array}{c}D \mathrm{~L}, \mathrm{CO} \\
\%\end{array}$ & $\begin{array}{l}\text { Clinical } \\
\text { course }\end{array}$ \\
\hline 1 & 68 & $\mathrm{~F}$ & II & 0 & 56.2 & + & NA & NA & Active \\
\hline 2 & 24 & M & II & 80 & 44.1 & + & 88 & 103 & Inactive \\
\hline 3 & 57 & $\mathrm{~F}$ & II & 0 & 24.6 & - & 97 & 102 & Active \\
\hline 4 & 64 & $\mathrm{~F}$ & II & 0 & 11.9 & - & NA & NA & Inactive \\
\hline 5 & 45 & $\mathrm{~F}$ & III & 0 & 16.0 & - & NA & NA & Active \\
\hline 6 & 26 & $\mathrm{M}$ & II & 0 & 9.9 & - & 86 & 93 & Inactive \\
\hline 7 & 57 & $\mathrm{~F}$ & II & 0 & 15.3 & + & NA & NA & Active \\
\hline 8 & 29 & M & II & 200 & 18.5 & - & 91 & NA & Inactive \\
\hline 9 & 34 & $\mathrm{~F}$ & I & 0 & NA & - & NA & NA & Unknown \\
\hline 10 & 42 & $\mathrm{~F}$ & III & 400 & 44.9 & - & 85 & 74 & Inactive \\
\hline 11 & 24 & M & II & 80 & 27.3 & + & 98 & 99 & Inactive \\
\hline 12 & 45 & M & II & 1260 & 23.2 & - & NA & NA & Inactive \\
\hline 13 & 35 & $\mathrm{~F}$ & II & 0 & 17.4 & - & NA & NA & Inactive \\
\hline 14 & 55 & $\mathrm{~F}$ & I & 60 & 19.9 & - & 108 & 109 & Inactive \\
\hline 15 & 64 & $\mathrm{~F}$ & 0 & 0 & 39.3 & - & 83 & NA & Active \\
\hline 16 & 53 & $\mathrm{M}$ & II & 990 & 51.1 & - & 90 & 74 & Unknown \\
\hline 17 & 24 & $\mathrm{M}$ & I & 100 & 29.5 & + & 110 & 76 & Inactive \\
\hline 18 & 31 & M & II & 250 & 31.5 & - & 92 & 93 & Inactive \\
\hline 19 & 24 & M & II & 0 & 15.8 & - & 100 & 88 & Inactive \\
\hline 20 & 66 & $\mathrm{M}$ & III & 1720 & 17.0 & + & 98 & NA & Active \\
\hline Mean \pm SD & $42 \pm 16$ & & & $472 \pm 580$ & $28.2 \pm 14.2$ & & $94 \pm 8$ & $91 \pm 13$ & \\
\hline
\end{tabular}

ACE: serum angiotensin converting enzyme (normal serum ACE level 6-22 U. $\mathrm{L}^{-1}$ ); extrathoracic: extrathoracic involvement; VC: vital capacity; DL,CO: diffusing capacity of the lung for carbon monoxide; M: male; F: female; NA: data not available; BI: Brinkman Index. Radiographic stage: stage I, hilar and/or mediastinal lymphoadenopathy, stage II, hilar and/or mediastinal lymphoadenopathy and lung parenchyma involvement, stage III, lung parenchyma involvement. 
Table 2. - Bronchoalveolar lavage data of sarcoidosis patients

\begin{tabular}{lccccc}
\hline $\begin{array}{l}\text { Patient } \\
\text { No. }\end{array}$ & $\begin{array}{c}\text { AM } \\
\%\end{array}$ & $\begin{array}{c}\mathrm{L} \\
\%\end{array}$ & $\begin{array}{c}\mathrm{N} \\
\%\end{array}$ & $\begin{array}{c}\mathrm{E} \\
\%\end{array}$ & $\begin{array}{c}\text { CD4/CD8 } \\
\text { ratio }\end{array}$ \\
\hline 1 & 41 & 51 & 7 & 1 & 9.3 \\
2 & 42 & 56 & 0 & 2 & 7.7 \\
3 & 50 & 50 & 0 & 0 & 11.1 \\
4 & 36 & 63 & 1 & 0 & 11.8 \\
5 & 6 & 83 & 8 & 3 & 10.6 \\
6 & 90 & 9 & 1 & 0 & 2.1 \\
7 & 45 & 55 & 0 & 0 & 19.2 \\
8 & 42 & 58 & 0 & 0 & 6.8 \\
9 & 57 & 42 & 1 & 0 & 10.3 \\
10 & 70 & 30 & 0 & 0 & 3.2 \\
11 & 43 & 57 & 0 & 0 & 5.9 \\
12 & 35 & 64 & 1 & 0 & 14.5 \\
13 & 80 & 18 & 2 & 0 & 4.3 \\
14 & 77 & 23 & 0 & 0 & 10.0 \\
15 & 40 & 58 & 1 & 1 & 6.9 \\
16 & 54 & 46 & 0 & 0 & 12.7 \\
17 & 56 & 44 & 0 & 0 & 1.6 \\
18 & 58 & 42 & 0 & 0 & 0.6 \\
19 & 22 & 53 & 3 & 2 & 6.7 \\
20 & 84 & 14 & 1 & 1 & $\mathrm{NA}$ \\
Mean \pm SD & $52 \pm 20$ & $46 \pm 19$ & $1.3 \pm 2.3$ & $0.5 \pm 0.9$ & $8.2 \pm 4.8$ \\
\hline A & &
\end{tabular}

AM: alveolar macrophages; L: lymphocytes; N: neutrophils; E: eosinophils; CD4/CD8 ratio; the ratio of the number of CD4+ T cells to that of CD8+ T-cells, determined by flow cytometry; NA: data not available. Cell differentials: expressed as percentage of total cells. according to the number of nuclei labelled in $1 \mathrm{~mm}^{2}$. The frequency of TUNEL positive cells in BAL cells was quantified according to the number of nuclei stained in percentage. The quantitative results of TUNEL are shown in table 3. Three independent evaluations were performed by three investigators (K. Kuwano, N. Hagimoto, H. Miyazaki). All agreed on the decision of positivity for each kind of cells in each specimen. Prominent intranuclear TUNEL staining was mainly seen in epithelioid histiocytes within granulomas in 12 of $20(60 \%)$ cases (fig. 1A, and B). Positive signals for TUNEL were also detected in some lymphocytes and macrophages. On the other hand, none of the ten normal lung parenchyma specimens exhibited positive signals (fig. 1C). Positive TUNEL signals were also found in BAL lymphocytes from 6 of $11(54 \%)$ patients with sarcoidosis, but little in macrophages (fig. 1D). There was no positive signal in BAL cells from normal control subjects (fig. 1E).

\section{Immunohistochemistry for Fas protein}

For immunohistochemistry, the frequency of Fas expression was graded from 0 to 3 according to the percentage of cells stained: graded as $0,<10 \% ; 1,10-20 \% ; 2,20-50 \%$; $3,>50 \%$ of the cells. The results of immunohistochemistry were assessed by three independent tissue evaluations. A summary of the results of the immunohistochemistry is shown in table 3. The immunoreactivity for Fas was detected within granulomas of all 20 patients with sarcoidosis. The most prominent expression of Fas was distributed

Table 3. - The quantitative results of terminal deoxynucleotidyl transferase-mediated biotin nick end labelling (TUNEL) and immunohistocytochemistry in sarcoidosis

\begin{tabular}{|c|c|c|c|c|c|c|}
\hline \multirow{3}{*}{$\begin{array}{l}\text { Patient } \\
\text { No. }\end{array}$} & \multicolumn{3}{|c|}{ TBLB(granulomatous lesion) } & \multicolumn{3}{|c|}{ BALF } \\
\hline & \multicolumn{2}{|c|}{ TUNEL } & \multirow{2}{*}{$\begin{array}{l}\text { Fas protein } \\
\text { grade** }\end{array}$} & \multirow{2}{*}{$\begin{array}{c}\text { TUNEL } \\
\text { positive cells } \\
\text { in percentage }\end{array}$} & \multirow{2}{*}{$\begin{array}{l}\text { Fas protein } \\
\text { grade** }\end{array}$} & \multirow{2}{*}{ FasL mRNA } \\
\hline & grade* & $\begin{array}{c}\text { positive } \\
\text { cells } \cdot \mathrm{mm}^{-2}\end{array}$ & & & & \\
\hline 1 & 0 & 0 & 1 & NA & NA & + \\
\hline 2 & 2 & 82 & 3 & 5 & 1 & + \\
\hline 3 & 0 & 1 & 3 & 0 & 1 & + \\
\hline 4 & 0 & 2 & 3 & 7.5 & 2 & - \\
\hline 5 & 0 & 63 & 3 & 1.5 & 1 & + \\
\hline 6 & 3 & 124 & 3 & 1.5 & 1 & + \\
\hline 7 & 0 & 0 & 2 & 0.5 & 2 & + \\
\hline 8 & 1 & 24 & 3 & 0 & 1 & - \\
\hline 9 & 2 & 64 & 2 & 0 & 1 & + \\
\hline 10 & 0 & 10 & 2 & 0 & 1 & + \\
\hline 11 & 2 & 36 & 3 & 0 & 1 & - \\
\hline 12 & 1 & 27 & 3 & 2 & 1 & - \\
\hline 13 & 1 & 16 & 3 & NA & 2 & + \\
\hline 14 & 0 & 3 & 2 & NA & 1 & + \\
\hline 15 & 0 & 2 & 3 & NA & 1 & - \\
\hline 16 & 1 & 23 & 1 & NA & 1 & + \\
\hline 17 & 2 & 80 & 3 & NA & 2 & + \\
\hline 18 & 2 & 46 & 1 & NA & 2 & + \\
\hline 19 & 2 & 44 & 3 & NA & 1 & + \\
\hline 20 & 1 & 22 & 2 & NA & 1 & + \\
\hline
\end{tabular}

TBLB: transbronchial lung biopsy; BALF: bronchoalveolar lavage fluid; mRNA: messenger ribonucleic acid; NA: data not available. *: graded as $0,<10 \% ; 1,10-20 \% ; 2,20-50 \% ; 3,>50 \%$, according to the percentage of nuclei stained; **: graded as $0,<10 \% ; 1,10-$ $20 \% ; 2,20-50 \% ; 3,>50 \%$, according to the percentage of cells stained. 

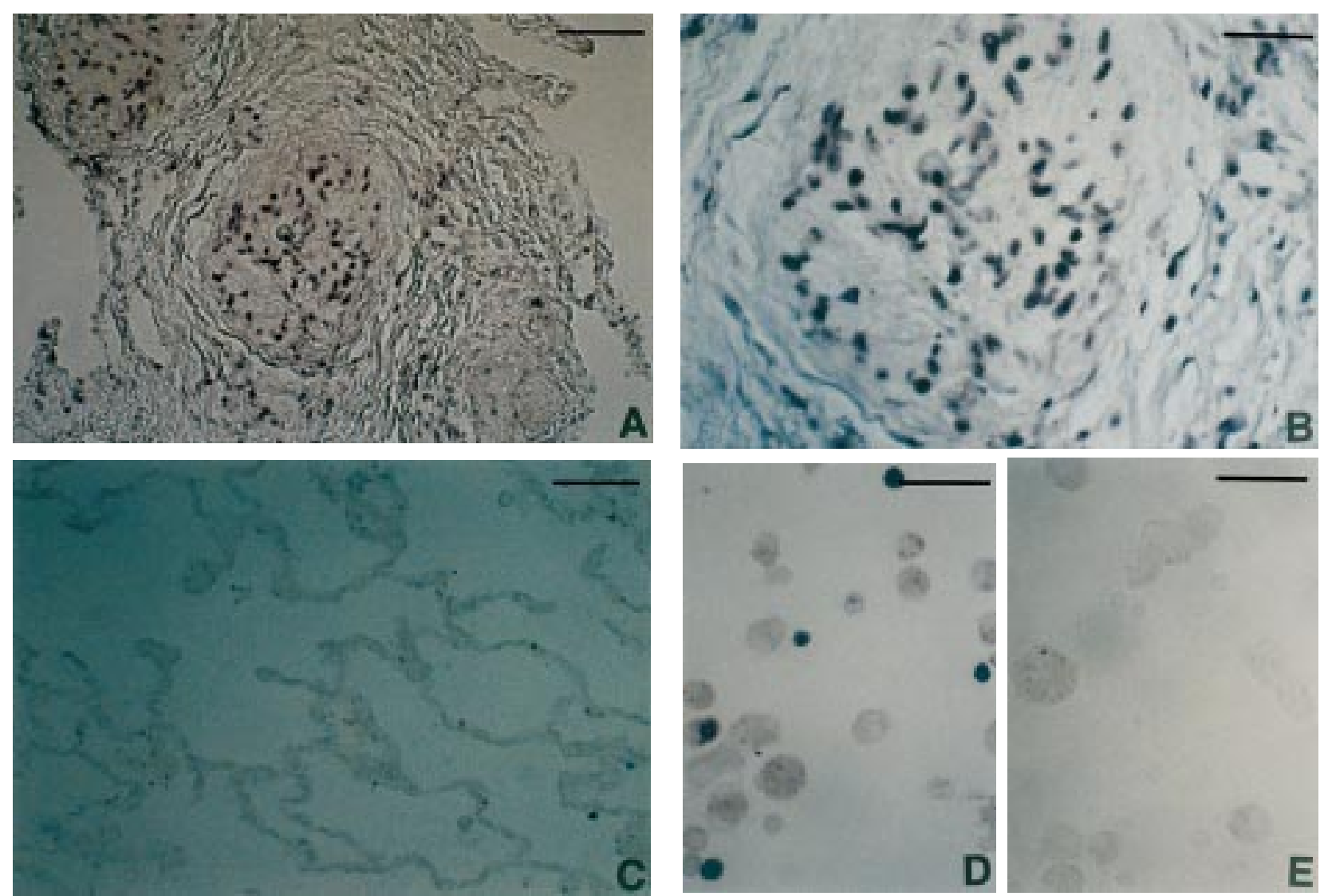

Fig. 1. - Representative results of terminal deoxynucleotidyl transferase-mediated biotin nick end-labelling (TUNEL) performed on lung tissue cells. TUNEL positive signals were found within granulomas in sarcoidosis (A, B), but not in normal lung parenchyma (C). TUNEL positive signals were found in bronchoalveolar lavage (BAL) lymphocytes from patients with sarcoidosis (D), but not in BAL cells from normal lung parenchyma (E). (Internal scale bars $\mathrm{A}$ and $\mathrm{C}=80 \mu \mathrm{m}, \mathrm{C}, \mathrm{D}$ and $\mathrm{E}=40 \mu \mathrm{m}$ ).

in the cytoplasm of epithelioid histiocytes and multinucleated giant cells contained within granuloma (fig. 2A). Positive signals were also seen in some alveolar macrophages surrounding granuloma and in a few lymphocytes (fig. 2B). There was no positive signal in normal lung parenchyma (fig. 2C). Fas expression was also detectable in BAL lymphocytes and macrophages from patients with sarcoidosis (fig. 2D), but not from normal lung parenchyma (fig. 2E).

\section{Immunohistochemistry for FasL protein}

Immunohistochemistry was performed for FasL protein in eight cases. FasL protein was detected in three of eight cases. FasL protein was localized in lymphocytes within and surrounding granuloma in lung tissues from patients with sarcoidosis (fig. $3 \mathrm{~A}-\mathrm{C}$ ). The positive signals for FasL protein were localized, and detected in $<10 \%$ of lymphocytes. FasL protein was not detectable in normal lung parenchyma (fig. 3D).

RT-PCR analysis and RT in situ PCR analysis for FasL $m R N A$

RT-PCR analysis for FasL mRNA in BAL cells showed specific hybridizing bands for FasL mRNA in 15 of 20
(75\%) cases of sarcoidosis (fig. 4A), but only in one of 10 normal lung parenchyma. The expression of FasL mRNA was detected by RT in situ PCR in BAL lymphocytes from 10 of 15 patients with sarcoidosis which were positive by RT-PCR (fig. 4B). A positive control of RT in situ PCR for FasL mRNA, in which the DNase step was not performed, demonstrated intense nuclear signals (fig. 4C). A negative control of RT in situ PCR for FasL mRNA, in which the DNase step was performed, and the RT step was eliminated, did not show any signals (fig. 4D).

Association between the results of TUNEL and Fas/ FasL expression

There was no significant correlation between the results of TUNEL and the expression of Fas/FasL protein or FasL mRNA in this study (Fisher's exact probability test).

Association between the results of TUNEL and clinical features

The results of TUNEL in granulomatous lesions correlated with the clinical course of disease ( $p<0.05$, Fisher's exact probability test) (table 4). Neither the results of TUNEL nor the expression of FasL mRNA correlated 

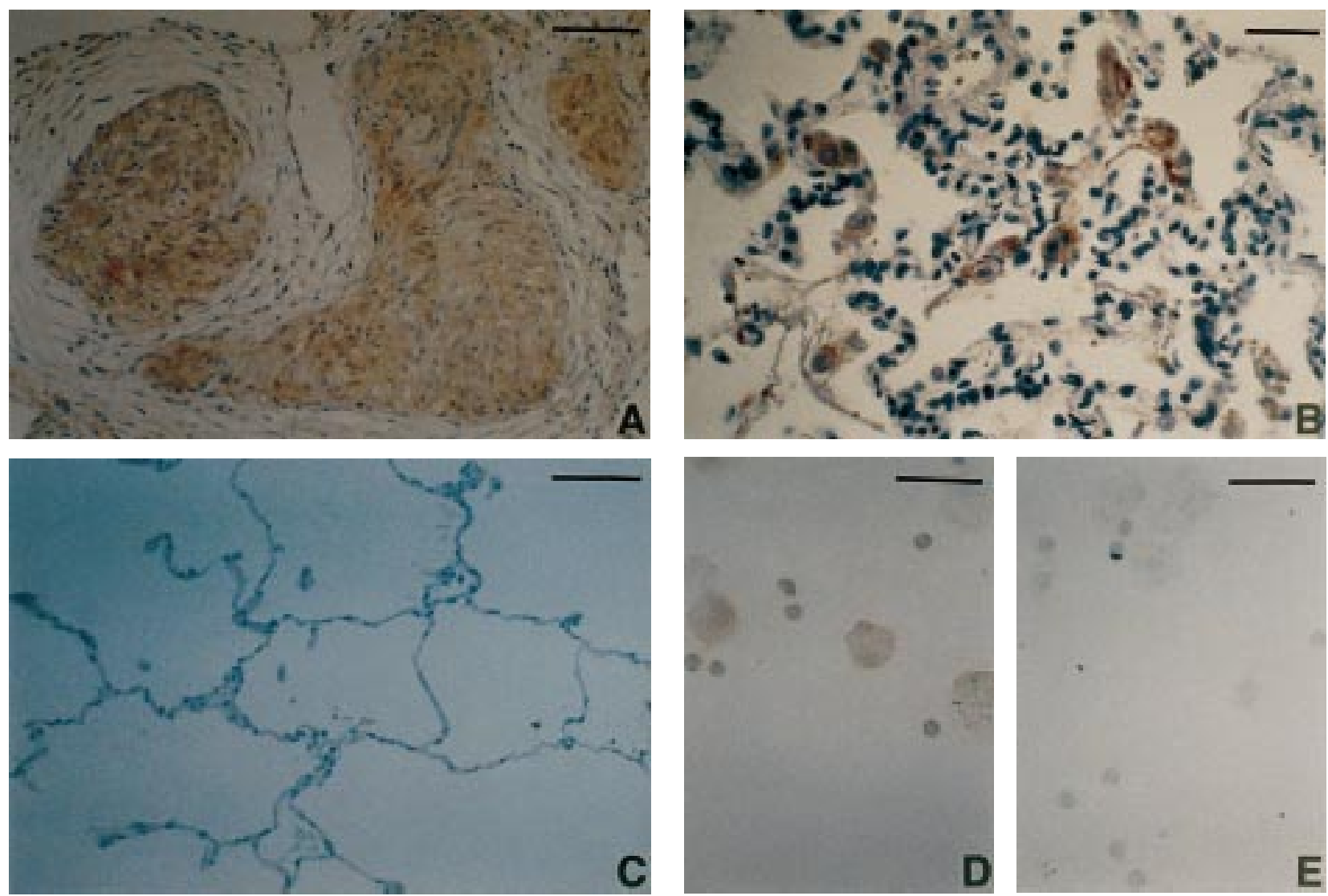

Fig. 2. - Immunohistochemical localization of Fas. Fas expression was seen in epithelioid histiocytes and multinucleated giant cells (A). Positive signals were also seen in alveolar macrophages and lymphocytes surrounding granuloma (B). There was no positive signal in normal lung parenchyma (C). Positive signals were also found in bronchoalveolar lavage (BAL) macrophages and lymphocytes from patients with sarcoidosis (D), but not in BAL cells from normal lung parenchyma (E). (Internal scale bars $\mathrm{A}$ and $\mathrm{C}=80 \mu \mathrm{m}, \mathrm{C}, \mathrm{D}$ and $\mathrm{E}=40 \mu \mathrm{m}$ ).

with the number of lymphocytes, lymphocyte percentage or $\mathrm{CD} 4 / \mathrm{CD} 8$ ratio in BAL fluid, serum angiotension converting enzyme (ACE) levels or the presence of extrathoracic involvement (Student's t-test).

\section{Discussion}

The granulomatous inflammation in sarcoidosis usually resolves spontaneously. In this study, TUNEL detected prominent positive signals in epithelioid histiocytes, lymphocytes and macrophages within or surrounding sarcoid granulomas. Furthermore, the results of TUNEL correlated with the clinical course of disease estimated by radiographic and clinical findings. The majority of patients with TUNEL positive signals improved during the follow-up period. Therefore, apoptosis in epithelioid histiocytes and inflammatory cells may play a role in determining the course of granulomatous inflammation.

The elimination by apoptosis of both infiltrating leukocytes and proliferating resident cells has emerged as an important mechanism promoting the resolution of inflammation and guarding against post-inflammatory scarring and fibrosis $[13,14]$. Repair after an acute lung injury also requires the elimination of proliferating mesenchymal and inflammatory cells from the alveolar airspace or alveolar walls [6]. Failure to clear unwanted cells by apop- tosis will prolong the inflammation because of the release of their toxic contents.

Alveolitis is most likely the earliest detectable manifestation of lung injury in pulmonary fibrosis [15], and loss of normal epithelial cells after irreparable damage may lead to pulmonary fibrosis. In vivo evidence was found indicating that the programme of apoptosis was available to bronchiolar and alveolar epithelial cells in bleomycininduced pulmonary fibrosis in mice [11]. It was also described that the DNA strand breakage were a characteristic of apoptosis detected by TUNEL in bronchiolar and alveolar epithelial cells in idiopathic pulmonary fibrosis (IPC) [9]. In contrast to IPF, positive signals for TUNEL were limited to the cells composing granulomatous inflammation in sarcoidosis, and the granulomatous inflammation is usually resolved without remaining fibrosis. These results suggest that epithelioid histiocytes, macrophages, and lymphocytes were selectively eliminated by physiologically regulated mechanisms in the course of granulomatous inflammation.

It was demonstrated that Fas was expressed in bronchiolar and alveolar epithelial cells in normal lung tissues [16], and the authors found that the Fas expression was upregulated in bronchial and alveolar epithelial cells in IPF [17]. In contrast to IPF, the Fas expression was upregulated in epithelioid histiocytes, macrophages, and lymphocytes in sarcoidosis. These results are compatible with those of TUNEL staining. The upregulation of Fas 

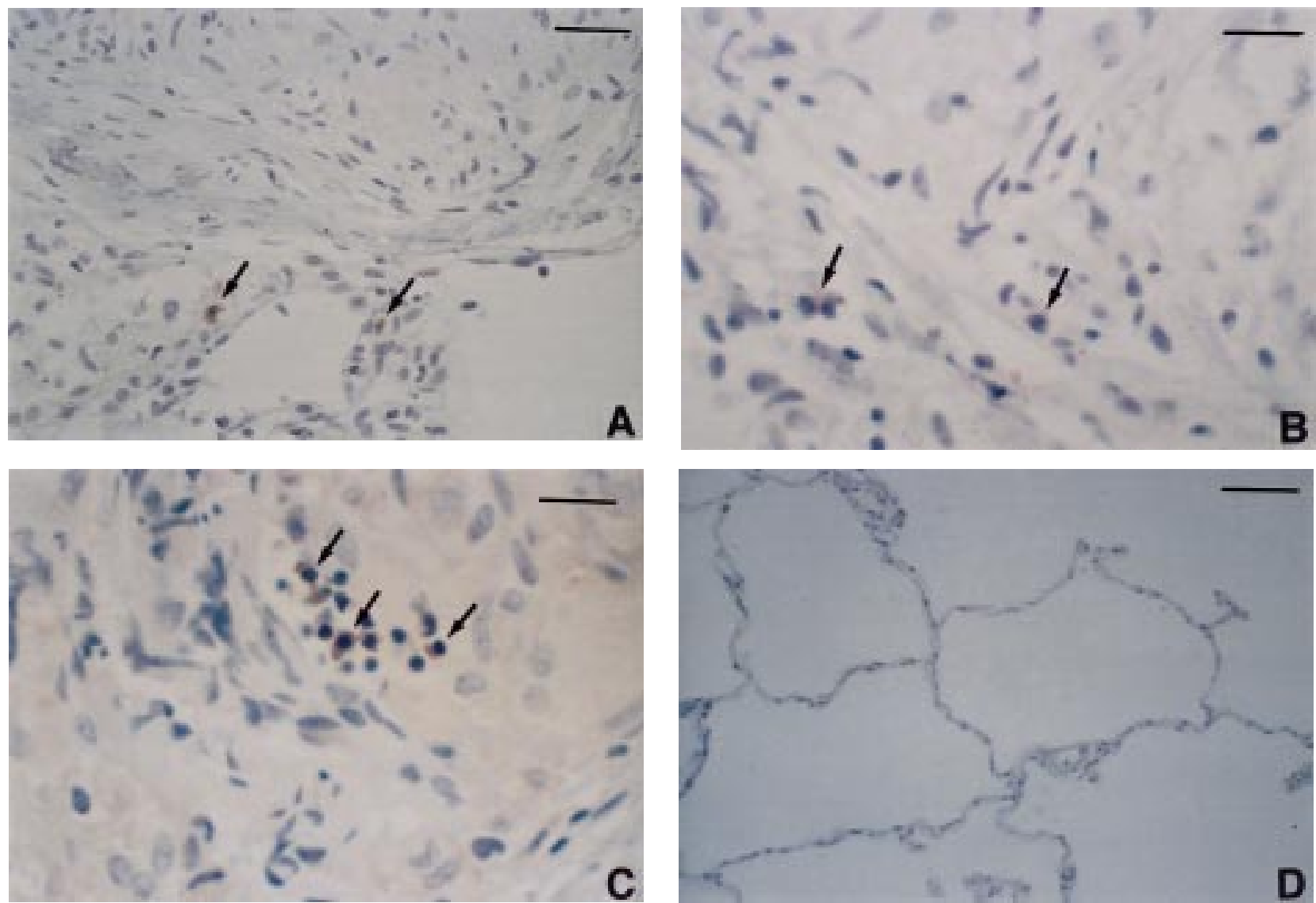

Fig. 3. - Immunohistochemical localization of FasL. FasL protein was expressed in lymphocytes surrounding granuloma (A and B, arrows). FasL protein was also expressed in lymphocytes within granuloma (C, arrows). There was no positive signal in normal lung parenchyma (D). (Internal scale bars $\mathrm{A}$ and $\mathrm{D}=80 \mu \mathrm{m}, \mathrm{B}$ and $\mathrm{C}=40 \mu \mathrm{m})$.

limited to inflammatory cells may reflect the physiologically regulated apoptosis in sarcoidosis.

FasL mRNA was detected in BAL lymphocytes. FasL protein was localized in lymphocytes within and surrounding the granuloma in lung tissue from patients with sarcoidosis. While FasL mRNA was detected in 15 of 20 cases $(75 \%)$ by RT-PCR, FasL protein was detected in only three of eight cases by the immunohistochemistry. All three FasL protein positive cases showed expression of FasL mRNA in BAL lymphocytes assessed by RT in situ PCR. There may be some reasons for the low incidence of FasL protein expression. Firstly, the sensitivity of immunohistochemistry for FasL protein may not be sensitive enough. This may be due to the fact that the specimens were formalin-fixed, paraffin-embedded tissues, and not fresh frozen tissues. Secondly, since the expression of FasL protein was scattered, FasL protein could only be detected in a few cases by immunohistochemistry using the small tissues obtained by TBLB. FasL expression was observed in lymphocytes in granulomatous lung tissue, where the Fas expression was upregulated and TUNEL positive cells were found. MiLiK et al. [18] demonstrated that apoptosis contributes to the elimination of lung lymphocytes during physiological pulmonary immune responses, and requires normal expression of Fas and FasL. Therefore, the Fas and FasL expression in BAL lymphocytes may be relevant to the regulation of inflammatory reaction by inducing apoptosis in BAL lymphocytes. It is also speculated that FasL expressed in lymphocytes within and surrounding the granulomas may induce apoptosis in epithelioid histiocytes, macrophages, or lymphocytes where Fas expression is upregulated.

However, Fas and FasL expression in this study did not correlate with the results of TUNEL or with clinical findings, while the results for TUNEL correlated with the spontaneous resolution of disease evaluated by radiographic and clinical findings. Resting T-cells or very recently activated T-cells do not undergo apoptosis in response to signals delivered through Fas. Rather, sensitivity to Fas-induced apoptosis develops 4-6 days after activation, and may be fostered by exposure to growth-promoting cytokines [19]. Therefore, some trophic factors, such as spontaneous interleukin (IL)-2 production known to occur in sarcoidosis or the production of other survival factors by lung parenchymal cells may reduce the susceptibility to Fas-mediated apoptosis of activated Tlymphocytes and also other inflammatory cells in sarcoidosis. In fact, pulmonary T-lymphocytes from patients with sarcoidosis, but not from normal subjects, secrete large quantities of a chemotactic factor for monocytes $[20,21]$, which results in a virtually continuous survival or supply of monocytes that eventually become the epithelioid cells of pulmonary granulomas. Therefore, since the interaction between death and survival factors appeared to be complex, there may be no correlation between Fas/FasL expression and clinical course. 

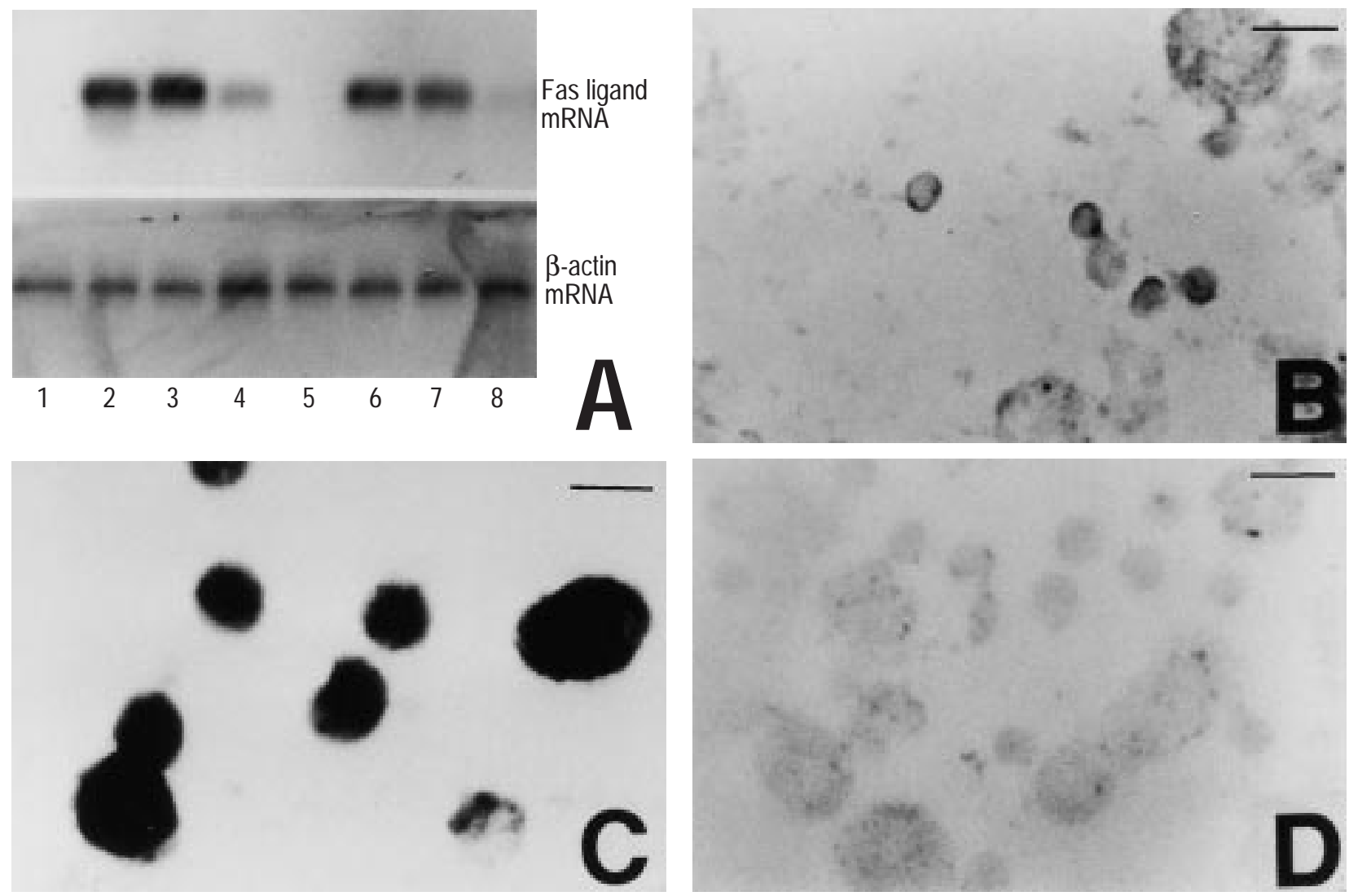

Fig. 4. - Representative results of reverse transcriptase (RT)-polymerase chain reaction (PCR) and RT in situ PCR for FasL messenger ribonucleic acid (mRNA) in bronchoalveolar lavage (BAL) cells. RT-PCR for FasL and $\beta$-actin mRNA (A). RT in situ PCR for FasL mRNA in BAL cells from patients with sarcoidosis (B). A positive control of RT in situ PCR for FasL mRNA in which the deoxyribonuclease (DNase) digestion step was eliminated (C). A negative control of RT in situ PCR for FasL mRNA in which the tissue was treated with DNase I and the RT step was eliminated (D). (Internal scale bars $=40 \mu \mathrm{m})$.

Since the number of the cases investigated in this study was small, longitudinal follow-up of a larger group of patients is needed to elucidate the precise roles of apoptosis and Fas/FasL pathway in the resolution of granulomatous inflammation.

In conclusion, the occurrence of deoxyribonucleic acid strand breakages were demonstrated as a characteristic of apoptosis and Fas expression was shown in the epithelioid histiocytes within granulomas and in nearby inflammatory cells. It was also demonstrated that the degree of deoxyribonucleic acid strand breakages correlated with the spontaneous resolution of disease. Furthermore, upregulation of FasL was observed in lymphocytes in the granulomatous region and in bronchoalveolar lavage fluid. These results suggest that apoptosis may be associated with the course of granulomatous inflammation in pulmonary sarcoidosis.

Table 4. - Correlation between the results of terminal deoxynucleotidyl transferase-mediated biotin nick end-labelling (TUNEL) and clinical course

\begin{tabular}{lccc}
\hline Clinical course & Positive & Negative & Total \\
\hline Inactive & 9 & 3 & 12 \\
Active & 1 & 5 & 6 \\
Total & 10 & 8 & 18 \\
\hline
\end{tabular}

\section{References}

1. Itoh $\mathrm{N}$, Yonehara $\mathrm{S}$, Ishii $\mathrm{A}$, et al. The polypeptide encoded by the cDNA for human cell surface antigen Fas can mediate apoptosis. Cell 1991; 66: 233-243.

2. Suda T, Takahashi T, Golstein P, Nagata S. Molecular cloning and expression of the Fas ligand, a novel member of the tumor necrosis factor family. Cell 1993; 75: 11691178.

3. Dhein J, Walczak H, Baumler C, Debatin KM, Krammer PH. Autocrine T-cell suicide mediated by APO-1/(Fas/ CD95). Nature 1995; 373: 438-441.

4. Brunner T, Mogil RJ, LaFace D, et al. Cell-autonomous Fas (CD95)/Fas-ligand interaction mediates activationinduced apoptosis in T-cell hybridomas. Nature 1995; 373: 441-444.

5. Ju ST, Panka DJ, Cui H, et al. Fas(CD95)/FasL interactions required for programmed cell death after T-cell activation. Nature 1995; 373: 444-448.

6. Polunovsky VA, Chen B, Henke C, et al. Role of mesenchymal cell death in lung remodeling after injury. $J$ Clin Invest 1993; 92: 388-397.

7. Shin RW, Iwaki T, Kitamoto T, Tateishi J. Hydrated autoclave pretreatment enhances tau immunoreactivity in formalin-fixed normal and Alzheimer's disease brain tissues. Lab Invest 1991; 64: 693-702.

8. Gavrieli Y, Sherman Y, Ben SS. Identification of programmed cell death in situ via specific labeling of nuclear DNA fragmentation. $J$ Cell Biol 1992; 119: 493-501. 
9. Kuwano K, Kunitake R, Kawasaki M, et al. P21Waf1/ Cip1/Sdi1 and p53 expression in association with DNA strand breaks in idiopathic pulmonary fibrosis. $\mathrm{Am} J$ Respir Crit Care Med 1996; 154: 477-483.

10. Wilkinson M. Purification of RNA, Essential Molecular Biology: A Practical Approach. New York, Oxford University Press, 1991.

11. Hagimoto N, Kuwano K, Nomoto N, Kunitake R, Hara N. Apoptosis and expression of Fas/Fas ligand mRNA in bleomycin-induced pulmonary fibrosis in mice. $\mathrm{Am} \mathrm{J}$ Respir Cell Mol Biol 1997; 16: 91-101.

12. Nuovo G. PCR in situ Hybridization: Protocols and Applications. 2nd edn. New York, Raven Press, 1994.

13. Haslett C. Resolution of acute inflammation and the role of apoptosis in the tissue fate of granulocytes. Clin Sci 1992; 83: 639-648.

14. Cox G, Crossley J, Xing Z. Macrophage engulfment of apoptotic neutrophils contributes to the resolution of acute pulmonary inflammation in vivo. Am J Respir Cell Mol Biol 1995; 12: 232-237.

15. Crystal RG, Bitterman PB, Rennard SI, Hance AJ, Keogh BA. Interstitial lung diseases of unknown cause. Disorders characterized by chronic inflammation of the lower respiratory tract. N Engl J Med 1984; 310: 235-244.
16. Leithauser F, Dhein J, Mechtersheimer G, et al. Constitutive and induced expression of APO-1, a new member of the nerve growth factor/tumor necrosis factor receptor superfamily, in normal and neoplastic cells. Lab Invest 1993; 69: 415-429.

17. Kuwano K, Miyazaki H, Hagimoto N, et al. The involvement of Fas-Fas ligand pathway in fibrosing lung diseases. Am J Respir Cell Mol Biol 1999; 20: 53-60.

18. Milik AM, Buechner-Maxwell VA, Sonstein J, et al. Lung lymphocyte elimination by apoptosis in the murine response to intratracheal particulate antigen. $J$ Clin Invest 1997; 99: 1082-1091.

19. Herry I, Bonay M, Bouchonnet $\mathrm{F}$, et al. Extensive apoptosis of lung T-lymphocytes maintained in vitro. Am J Respir Cell Mol Biol 1996; 15: 339-347.

20. Gadek J. Maintenance of the alveolitis of sarcoidosis. In: Crystal RG, ed. Pulmonary Sarcoidosis: A Disease Characterized and Perpetuated by Activated Lung T-Lymphocytes. Ann Intern Med 1981; 94: 73-94.

21. Hunninghake GW, Gadek JE, Young RC Jr, Kawanami O, Ferrans VJ, Crystal RG. Maintenance of granuloma formation in pulmonary sarcoidosis by $\mathrm{T}$ lymphocytes within the lung. $N$ Engl J Med 1980; 302: 594-598. 